\title{
From the Judaean Desert to the Great Sea: Qumran in a Mediterranean Context
}

\author{
Dennis Mizzi \\ University of Malta \\ dennis.mizzi@um.edu.mt
}

\begin{abstract}
The time when Qumran was studied in splendid isolation is long gone, but much work remains to be done when it comes to situating the site in its wider context. In this paper, Qumran is contextualized, on the one hand, within the larger ecological history of the Mediterranean and, on the other, within the Mediterranean world of classical antiquity. Questions regarding the functions of the Qumran settlement are addressed from the perspective of "marginal zones" in the Mediterranean, which provides an ideal backdrop through which to illumine aspects of daily life at Qumran. Furthermore, it is shown how comparative case studies from the Graeco-Roman Mediterranean help us to nuance the discussion concerning "Hellenization" or "Romanization" with regard to Qumran. Finally, a new understanding of $\mathrm{L}_{4}$, which is here interpreted primarily as a dining room, is proposed on the basis of archaeological parallels from the GraecoRoman world. A pan-Mediterranean perspective, therefore, allows us to generate new insights on old questions and novel interpretations.
\end{abstract}

\section{Keywords}

Mediterranean - Hellenization and Romanization - agriculture and industry at Qumran - private libraries - dining practices - dining rooms - Qumran Locus 4

* I thank Jutta Jokiranta for inviting me to contribute a paper to this thematic issue of Dead Sea Discoveries. I also extend my gratitude to the two anonymous reviewers, whose comments were extremely valuable. 
The time when Qumran was studied in splendid isolation is long gone. This is not only the result of current archaeological practice, which prioritizes landscape and regional approaches to sites, but also because of clear indications that Qumran was indeed connected to surrounding settlements and integrated within the regional economy. ${ }^{1}$ This notwithstanding, the implications for the archaeology of Qumran have not been explored to their logical conclusion, partly because the sometimes divisive debate concerning the nature of the site has encumbered scholarly progress on this issue. The problem is that the question of connectivity has often been used as a key argument for or against a particular interpretation of the site. The difficulty with arguments of this sort, however, is that they mistake insularity for isolation.

This issue of Dead Sea Discoveries is dedicated to Qumran and the Dead Sea Scrolls in their Hellenistic context, and this provides an apt opportunity to explore the question of connectivity anew, albeit taking a very different approach. I propose to expand the parameters of contextualization and to situate Qumran, on the one hand, within the larger ecological history of the Mediterranean and, on the other, within the Mediterranean world of classical antiquity, an interconnected world that facilitated the movement of objects, peoples, and ideas. ${ }^{2}$ The aim of this paper is to highlight the benefits of a

1 See, for instance, Jürgen Zangenberg, "Wildnis unter Palmen? Khirbet Qumran im regionalen Kontext des Toten Meeres," in Jericho und Qumran: Neues zum Umfeld der Bibel, ed. Bernhard Mayer, ES 45 (Regensburg: Friedrich Pustet, 2000), 129-63; idem, "Opening Up Our View: Khirbet Qumran in a Regional Perspective," in Religion and Society in Roman Palestine: Old Questions, New Approaches, ed. Douglas R. Edwards (New York: Routledge, 2004), 170-87; Dennis Mizzi, The Archaeology of Khirbet Qumran: A Comparative Approach (DPhil. diss., University of Oxford, 2009); Joan E. Taylor and Shimon Gibson, "Qumran Connected: The Qumran Pass and Paths of the North-Western Dead Sea," in Qumran und die Archäologie: Texte und Kontexte, ed. Jörg Frey, Carsten Claußen, and Nadine Kessler, wUnT 278 (Tübingen: Mohr Siebeck, 2011), 163-209.

2 Together with the editors of this issue, I define the term "Hellenistic" very loosely to characterize, in broad strokes, the cultural milieu of large tracts of the Mediterranean world during the Hellenistic, Roman, and Byzantine periods, without implying a Greek or Roman cultural dominance or the disappearance of indigenous cultures. The Hellenistic empires created an inland and maritime network that facilitated cultural exchange and interaction between diverse peoples, a reality that was propagated further with the development of the Roman empire and the creation of the mare nostrum. In the context of Judaea, the Hasmonaeans ushered in an era of growth, marked by population expansion, the rise of urbanism, and wider international relations; after them, Herod opened up Judaea to an even wider array of influences and exchange networks. 
pan-Mediterranean ${ }^{3}$ perspective for generating new insights on old questions and novel interpretations. I divide the paper into three brief notes, each of which looks at different aspects of the archaeology of Qumran. The analysis is not exhaustive, and some of the observations are nothing but preliminary notes on ideas which will be explored in much greater detail in my upcoming monograph.

\section{Qumran and the Mediterranean: Some Reflections on the Functions of the Qumran Settlement}

The first note concerns the use of the Mediterranean as a backdrop for Qumran. In their magisterial work The Corrupting Sea, Peregrine Horden and Nicholas Purcell accentuate the fact that the Mediterranean is characterized by several microregions constituting diverse microecologies and microclimates, which in turn result in a diversity of local economies. ${ }^{4}$ Critically, for most of its history, life in the Mediterranean was marked by constant risk — caused by shortage of precipitation (and, therefore, the ever looming famine), climate adversity, difficult soils and terrains, natural disasters, and one could add warfare and

3 My definition of the ancient "Mediterranean" is broad and flexible, demarcating the region not by geographical or political borders but by the limits of connectivity, which reached their widest extent in the Hellenistic and Roman periods.

In scholarly literature, defining the borders of the Mediterranean remains an open-ended question. See the discussions or contributions in Fernand Braudel, The Mediterranean and the Mediterranean World in the Age of Philip II, 2 vols. (Berkeley: University of California Press, 1995); Peregrine Horden and Nicholas Purcell, The Corrupting Sea: A Study of Mediterranean History (Oxford: Blackwell, 200o); W. V. Harris, ed., Rethinking the Mediterranean (Oxford: Oxford University Press, 2005); David Abulafia, The Great Sea: A Human History of the Mediterranean (London: Allen Lane, 2011); Cyprian Broodbank, The Making of the Middle Sea: A History of the Mediterranean from the Beginning to the Emergence of the Classical World (London: Thames \& Hudson, 2013). I find Braudel's remarks particularly pertinent for my purposes: "The rule has been that Mediterranean civilization spreads far beyond its shores in great waves that are balanced by continual returns. What leaves the sea comes back and then departs once more.... The circulation of man and of goods, both material and intangible, formed concentric rings round the Mediterranean. We should imagine a hundred frontiers, not one, some political, some economic, and some cultural. When Goethe went to Italy, he reached the Mediterranean, not, as he says, when he crossed the Brenner Pass or later in the Tuscan Apennines. He had already reached it when he arrived at Ratisbon, the outpost of Catholicism on the great cultural frontier of the Danube, or even, further north again, right at the start of his journey, in Frankfurt, the city of the Römer" (Braudel, The Mediterranean, 170).

4 Horden and Purcell, The Corrupting Sea. 
raids - which, in Horden and Purcell's view, turned all Mediterranean microregions into "marginal zones."

The strategy to mitigate risk was threefold: diversity, storage, and redistribution. ${ }^{6}$ "Specialization is potentially lethal," and "the locality's degree of involvement with other places, will be seen to be of high importance." The only solution to persistent marginality, therefore, was the exploitation of a diverse array of natural resources, the production of surplus, and the maintenance of a trade network through which region-specific goods could be exchanged or shortages replenished. Connectivity was the key to survival in the ancient Mediterranean world. Two important observations Horden and Purcell make warrant quotation in full:

The peripheral environment of marsh, mountain, forest or sea was long undervalued by historians influenced by the cultural prejudice that privileges, as being more civilized, tilling the soil over other productive activities ... In point of fact, the areas that we often dismiss as least hospitable, or perceive as residual fragments of a landscape that was once hostile to humanity, are among the most diverse and complex portfolios of complementary productive opportunities. They offer, in most dramatic fashion, the opportunity of harnessing natural variety to buttress against natural risk ... the exploitation of what has seemed to be the marginal cannot be isolated from other parts of the economy. ${ }^{8}$

Subsistence is suicidal: it makes no provision for the bad year. Even the pursuit of self-sufficiency is an ethical tenet rather than a practice observable in reality ... In Mediterranean conditions, let us asseverate once more, overproduction is the only safe plan. So there is no incompatibility between protestations of autarky and producing surpluses for storage, exchange or redistribution: the latter is the way the former are made plausible. $^{9}$

It is worth revisiting Qumran from this perspective. Situated as it was in the Judaean Desert, Qumran was in a similarly precarious, marginal zone which lacked adequate supplies of water and fuel resources, and where cultivable

5 Horden and Purcell, The Corrupting Sea, 178-82.

6 Horden and Purcell, The Corrupting Sea, 175-230.

7 Horden and Purcell, The Corrupting Sea, 202 and 181, respectively.

8 Horden and Purcell, The Corrupting Sea, 182-83 and 197, respectively.

9 Horden and Purcell, The Corrupting Sea, 272-73. 
land was limited; moreover, the range of crops that could be cultivated was restricted owing to climate and soil factors, meaning that the Qumranites would have had to import basic staples such as olive oil, wine, and possibly grain; furthermore, the zone was prone to seismic activity, which would have meant additional expenses and the possible loss of stored produce if serious damage was caused to buildings and installations (cf. the earthquake of $31 \mathrm{BCE}$ ). At the same time, the Dead Sea region should not be underestimated despite its seeming marginality and inhospitality. Indeed, the region offered a wide range of important (and lucrative) resources, including the balsam plant, date palms, various medicinal shrubs, bitumen, and salt, among others. The exploitation and exportation of these resources would have generated the required revenue to import basic foodstuff and invest further into the local economy, thus mitigating risk and ensuring survival. Qumran may have been insular, but it could not afford to be isolated. ${ }^{10}$

This picture allows us to nuance one of the persistent debates about Qumran, namely that pertaining to the site's nature and function. Many interpretations have been proposed in this regard throughout the past seventy years, although many have failed to attract any adherents besides their original exponent(s).1 The so-called sectarian hypothesis, which posits a connection

10 On the basis of the present evidence, it is not possible to trace trade networks with any precision. Obvious hubs would have been the nearby town of Jericho and the village of 'Ein Gedi. Furthermore, Jericho would have provided connections to Jerusalem and, by extension, to a wider array of trade networks. Indeed, many of the chalkstone and glass vessels at Qumran likely came from Jerusalem, a major production and redistribution centre. Probably, foods and liquids travelled along the same routes.

Estimating the weight or volume of foods and liquids needed to sustain the inhabitants at Qumran, or the extent of economic productivity and exchange, is impossible to determine. This depends on a number of variables, including population size (which could have experienced constant fluctuations throughout the year) and socio-cultural practices.

11 For the purposes of this paper, and due to reasons of space, there is no need to cite all the literature. General overviews of the various theories about the site can be found in Magen Broshi and Hanan Eshel, "Qumran and the Dead Sea Scrolls: The Contention of Twelve Theories," in Religion and Society in Roman Palestine: Old Questions, New Approaches, ed. Douglas R. Edwards (London: Routledge, 2004), 162-69; Dennis Mizzi, "6o Years of Qumran Archaeology," Strata 29 (2011): 31-50; idem, "Qumran Period I Reconsidered: An Evaluation of Several Competing Theories," DSD 22 (2015): 1-42; idem, "Archaeology of Qumran," in The T\&T Clark Companion to the Dead Sea Scrolls, ed. George J. Brooke and Charlotte Hempel (London: T\&T Clark, forthcoming). 
between the settlement at Qumran and the Dead Sea Scrolls, ${ }^{12}$ is both the most convincing and the only theory to enjoy a quasi-consensus, even though it needs to be refined further. In retrospect, the scholarly discussion has been hampered by problems of definition and terminology as well as a tendency towards rigidity in the interpretation of the site. While some scholars do suggest that Qumran could have changed functions during its occupation in the first centuries $\mathrm{BCE}$ and $\mathrm{CE}$, for example, the approach to the site remains very much monolithic: Qumran was one thing in the Hasmonaean period and another in the Herodian period. ${ }^{13}$ Many scholarly views also betray a confusion between a site's function(s) and the identity of its inhabitants. Describing Qumran as a "sectarian settlement," for instance, tells us very little about its functions, not to mention that the term does not describe an architectural category or settlement type and that it gives the false impression that the settlement was largely of a "religious" nature. On the other hand, alternative hypotheses wrongly assume that determining the taxonomy of a settlement is tantamount to identifying its core essence or the nature of its inhabitants. ${ }^{14}$

However, it is utterly inconceivable that a settlement in the middle of the desert would have been devoted solely to study and prayer, or that it was cut off from regional economic networks. That would have been a recipe for disaster, and this is exactly why arguments about the site's connectivity or function(s) can never play a pivotal role in the identification of its inhabitants. Basically, such arguments are moot since Qumran-irrespective of who inhabited itwould have had to be both multifunctional and integrated within a regional system of production and distribution. Accordingly, Qumran could have been

12 For the classic view, see Roland de Vaux, Archaeology and the Dead Sea Scrolls, rev. ed. (London: Oxford University Press, 1973); Magen Broshi "The Archaeology of Qumran: A Reconsideration," in The Dead Sea Scrolls: Forty Years of Research, ed. Devorah Dimant and Uriel Rappaport, STDJ 10 (Leiden: Brill, 1992), 103-15; Jodi Magness, The Archaeology of Qumran and the Dead Sea Scrolls (Grand Rapids, MI: Eerdmans, 2002).

13 In making this argument, scholars also assume a change of the site's inhabitants, but this is unlikely. See Dennis Mizzi and Jodi Magness, "Was Qumran Abandoned at the End of the First Century вСЕ?" JBL 135 (2016): 301-20.

14 Certainly, advocates of the sectarian hypothesis have always acknowledged the undertaking of industrial activity at the site, but this aspect is generally minimized in favour of "religious" or "ritual" aspects. In contrast, alternative hypotheses tend to overemphasize non-"religious" elements. In fact, none of this has any bearing on whether or not Qumran was connected to the group(s) behind the Scrolls. There was no such thing as an architectural blueprint for a "sectarian settlement." What clinches the argument is the strong archaeological and contextual connections between the caves in which the Scrolls have been found and the settlement at Qumran. 
inhabited by a group related to the Dead Sea Scrolls—in which case, it could be called vaguely a "sectarian settlement" — while the site itself could have fulfilled a wide range of purposes.

Important among these were agriculture and industry. Scholars have proposed a wide variety of economic endeavours, including the cultivation of palm trees and the production of date products; ${ }^{15}$ the manufacture of medicines, unguents, and perfumes; ${ }^{16}$ tanning, leather-working, wool preparation and dyeing, glue manufacturing, rope making, and basketry, ${ }^{17}$ and pottery production. ${ }^{18}$ It is unlikely that all the proposed industries were actually undertaken at Qumran, and some suggestions are either unconvincing or lack supporting evidence altogether. Furthermore, it is important to make a distinction between primary and secondary industries, and between products intended for local consumption and those made for export. It is not my intention to discuss this in detail here, but I would especially highlight the economic significance of dates and salt (an industry that has often been overlooked or simply mentioned en passant), which were probably the most lucrative and commonly available resources in the region of Qumran. ${ }^{19}$ Nonetheless, the

15 Mizzi, The Archaeology of Khirbet Qumran.

16 For medicines and unguents, see Joan E. Taylor, The Essenes, the Scrolls, and the Dead Sea (Oxford: Oxford University Press, 2012), 304-40; eadem, "'Roots, Remedies and Properties of Stone': The Essenes, Qumran and Dead Sea Pharmacology," JJS 6o (2009): 226-44. For the cultivation of balsam and the production of perfume, see Robert Donceel and Pauline Donceel-Voûte, "Traces of Fragrance along the Dead Sea," RevQ 11 (1998): 93-124; Yizhar Hirschfeld, Qumran in Context: Reassessing the Archaeological Evidence (Peabody, MA: Hendrickson, 2004).

17 David Stacey and Gregory L. Doudna (with a contribution by Gideon Avni), Qumran Revisited: A Reassessment of the Archaeology of the Site and its Texts, BAR International Series 2520 (Oxford: Archaeopress, 2013), 52-65; David Stacey, "Seasonal Industries at Qumran," BAIAS 26 (2008): 7-29.

18 Cf. the kilns in L64 and L84. Many scholars uphold the view that pottery was manufactured at Qumran for local consumption. For pottery production on a commercial scale, see Yitzhak Magen and Yuval Peleg, "Back to Qumran: Ten Years of Excavation and Research, 1993-2004," in Qumran: The Site of the Dead Sea Scrolls: Archaeological Interpretations and Debates: Proceedings of a Conference held at Brown University, November 17-19, 2002, ed. Katharina Galor, Jean-Baptiste Humbert, and Jürgen Zangenberg, STDJ 57 (Leiden: Brill, 2006), 55-113.

19 Dates were a lucrative crop, and they appear to have been one of the most important Judaean exports following balsam. Indeed, Judaean dates seem to have been renowned in antiquity (cf. Pliny the Elder, Natural History 13.6-9), and the economic importance of the date palm is also hinted at by the fact that the tree became symbolic of Judaea on both Jewish and Roman coins. See also Magen Broshi and Hanan Eshel, "Was There 
point I want to make is that we do not have to choose, for it is improbable that the Qumranites specialized in any one industry - to reiterate, diversification would have been vital at Qumran. ${ }^{20}$

Although some scholars take this for granted, without going into further specifics, establishing that Qumran had an agricultural and/or industrial dimension is but a first step. It is also necessary to fill in the details and determine how the Qumranites could have gone about carrying out these various agricultural and industrial endeavours since this casts important light on their daily life and practices as well as their socio-cultural standing in the society of the time. Here, however, we encounter a brick wall owing to a dearth of evidence. What land did the Qumranites cultivate, and were they landowners or tenants working somebody else's land? From where did they harvest the resources of the Judaean Desert, and what rights did they have to these resources? How much produce did they export, and through what mechanisms did they distribute it? What trading networks were they connected to? What was Qumran's role in the regional economy? At this point, one enters into the

Agriculture at Qumran?" in Galor, Humbert, and Zangenberg, Qumran: The Site of the Dead Sea Scrolls, 249-52 (251); Joan. E. Taylor, "Khirbet Qumran in Period III," in Galor, Humbert, and Zangenberg, Qumran: The Site of the Dead Sea Scrolls, 133-46 (142-46).

Salt was one of the most crucial resources in the ancient world, primarily because of its preservative properties but also because of its use in various industries as well as medicine. See, for example, Annalisa Marzano, Harvesting the Sea: The Exploitation of Marine Resources in the Roman Mediterranean (Oxford: Oxford University Press, 2013), 123-42; Cristina Carusi, “'Vita Humanior Sine Sale Non Quit Degere': Demand for Salt and Salt Trade Patterns in the Ancient Greek World," in The Ancient Greek Economy: Markets, Household and City-States, ed. Edward M. Harris, David M. Lewis, and Mark Woolmer (Cambridge: Cambridge University Press, 2014), 337-55; Isabella Tsigarida, "Salt in Asia Minor: An Outline of Roman Authority Interest in the Resource," in Ownership and Exploitation of Land and Natural Resources in the Roman World, ed. Paul Erdkamp, Koenraad Verboven, and Arjan Zuiderhoek (Oxford: Oxford University Press, 2015), 27788. People in Judaea would have had to buy their household supply of salt either from producers in the west (by the Mediterranean coast) or the east (along the Dead Sea shore), and Qumran is likely to have been a major eastern supplier.

20 Especially pertinent to the present point is Philip F. Esler's recent monograph, Babatha's Orchard: The Yadin Papyri and an Ancient Jewish Family Tale Retold (Oxford: Oxford University Press, 2017). Esler highlights the precarious nature of the date industry, which was lucrative but also risky. Translated to Qumran, this means that the Qumranites could not have specialized in this industry alone. Rather, this would have been one of many economic undertakings. Indeed, the same installations at Qumran could have been used for any number of different industries, with the function to which they were put to use changing according to season or the availability of raw materials, for instance. 
realm of speculation, but data from the Graeco-Roman Mediterranean can help us fill some of the lacunae, not by providing conclusive answers or by supplying the missing evidence but by providing parameters of interpretation which allow us to determine what is and what is not plausible.

Irrespective of whether or not Qumran and 'Ein Feshkha were connected, ${ }^{21}$ it is not improbable that the Qumranites cultivated the land between the two sites, which was supplied with water by a number of springs. ${ }^{22}$ Even if the water was brackish, ${ }^{23}$ this would have been suitable for the cultivation of the date palm, which was, as noted above, one of the most important resources in the region. And even though Qumran sits on a plateau above this tract of land, there is no reason to reject the possibility that its inhabitants cultivated the land below and south of it. In fact, if the so-called Yahad ostracon refers to a transfer of property to the Qumranites, then it is also evident that the Qumranites owned land in Jericho. ${ }^{24}$ Furthermore, since the establishment of the settlement at Qumran predates that at 'Ein Feshkha, ${ }^{25}$ there is even less reason to assume that the latter controlled the entire area between it and Qumran. If the two settlements were unrelated, it is not implausible that they cultivated different parts of the tract of land between them, while sharing water rights. In this regard, it is very instructive to look at the various water contracts and water-sharing systems in the Roman world. ${ }^{26}$

21 This is not the venue to enter into this conversation, for which see de Vaux, Archaeology and the Dead Sea Scrolls, 59-6o, 84; Hirschfeld, Qumran in Context, 183, 185, 209; JeanBaptiste Humbert, "Some Remarks on the Archaeology of Qumran," in Galor, Humbert, and Zangenberg, Qumran: The Site of the Dead Sea Scrolls, 19-39 (24-27); Joan E. Taylor, "Ein Fashkha," EJ 6:256; Magness, Archaeology of Qumran, 220-23; Broshi and Eshel, "Was There Agriculture at Qumran?".

22 See Hirschfeld, Qumran in Context, 183-85, Fig. 107.

23 See Magness, Archaeology of Qumran, 21.

24 See Ada Yardeni, "A Draft of a Deed on an Ostracon from Khirbet Qumrân," IEJ 47 (1997): 233-37; Émile Puech, "L'ostracon de Khirbet Qumrân (KhQ1996/1) et une vente de terrain à Jéricho, témoin de l'occupation essénienne à Qumrân," in Flores Florentino: Dead Sea Scrolls and Other Early Jewish Studies in Honour of Florentino García Martínez, ed. Anthony Hilhorst, Émile Puech, and Eibert J. C. Tigchelaar, JSJSup 122 (Leiden: Brill, 2007), $1-29$.

25 For the chronology of 'Ein Feshkha, see Magness, Archaeology of Qumran, 217-19.

26 Christer Bruun, "Water Use and Productivity in Roman Agriculture: Selling, Sharing, Servitudes," in Erdkamp, Verboven, and Zuiderhoeck, Ownership and Exploitation of Land, 132-49. Cf. the Judaean Desert documents for the practice of water sharing, for which see Hannah M. Cotton and Ada Yardeni, "Greek Documentary Texts," in DJD 27: 133-279 (e.g., 212). 
Similarly, there is rich documentary evidence which sheds much needed light on the question of land ownership in Judaea. Some scholars doubt the plausibility of an independent community exploiting the rich resources of the Dead Sea next door to the royal estates in Jericho. ${ }^{27}$ Nonetheless, documentary and literary sources from various regions of the Mediterranean reveal a complex picture in terms of land ownership and exploitation during the Hellenistic and Roman periods. For instance, royal land or imperial estates need not necessarily have been run directly by the king or emperor since they could also be hired out to tenants (not to be confused with hired workers), who worked the land independently and paid rent in money or in kind; significantly, tenants could in turn pass on the land as inheritance. More importantly, it is becoming increasingly evident that privately owned land was more common than previously thought. ${ }^{28}$ There is no reason, therefore, why the land between Qumran and 'Ein Feshkha could not have been privately owned land or else leased from the state (but run independently). After all, the aforementioned Yahad ostracon proves that the Qumranites probably did own land. ${ }^{29}$ Of course, none of these observations can be proven conclusively owing to a lack of data, but case

27 See, for instance, Stacey and Doudna, Qumran Revisited, 72.

28 See, for example, Hannah M. Cotton, "Rent or Tax Receipt from Maoza," ZPE 100 (1994): 547-57; eadem, "Land Tenure in the Documents from the Nabataean Kingdom and the Roman Province of Arabia," ZPE 119 (1997): 255-65; Hannah M. Cotton and Jonas C. Greenfield, "Babatha's Property and the Law of Succession in the Babatha Archive," ZPE 104 (1994): 211-24; idem, "Babatha's 'Patria': Maḥoza, Maḥoz, 'Eglatain and Zo'ar," ZPE 107 (1995): 126-34. And see further J. G. Manning, Land and Power in Ptolemaic Egypt: The Structure of Land Tenure 332-30 BCE (Cambridge: Cambridge University Press, 2003); Kyle Harper, "Landed Wealth in the Long Term: Patterns, Possibilities, Evidence," in Erdkamp, Verboven, and Zuiderhoeck, Ownership and Exploitation of Land, 43-61; Dennis P. Kehoe, "Property Rights over Land and Economic Growth in the Roman Empire," in Erdkamp, Verboven, and Zuiderhoeck, Ownership and Exploitation of Land, 88-106. See also the discussion in Jack Pastor, Land and Economy in Ancient Palestine (London: Routledge, 1997).

29 Questions of whether or not the Hasmonaeans would have allowed their alleged enemies to own such lucrative lands is a moot point. This depends on a specific reading of the Scrolls, and it is well known that reconstructing history from the Scrolls is very difficult. It also assumes that the rhetoric in the Scrolls is a mirror image of lived life at Qumran, when rhetoric could have been confined to the literary imaginary. This is exactly why the analysis of texts and archaeology should take place separately at first.

Incidentally, the fact that the quality of the water makes it "only marginally potable ... [explaining] why there were no major, multi-period settlements in antiquity (or even today) at Ein Feshkha, Ein el-Ghuweir, and Ein et-Tureibeh, in contrast to the sweet-water oases at Jericho and Ein Gedi" and why intensive occupation was limited to a very brief period of less than a century in the late first century вСЕ and first century CE (Magness, 
studies from the region and elsewhere in the Graeco-Roman Mediterranean show that such a scenario is highly plausible. And this is the best we can do considering the nature of the evidence.

Despite the above characterization of the settlement at Qumran, one has to be cautious with the use of such fixed labels as "farmstead," "villa," or "agroindustrial site" to describe the site as they do little to advance our understanding of it. The problem with these terms is that they are too general or too vague, and while some may work for studies focusing on settlement patterns, they fail to illumine facets of daily life at any one particular site. One key consideration to keep in mind is that form does not equal function. No matter how similar two or more sites are, it is not a given that they functioned in the same manner or that their inhabitants practised similar lifestyles. As active agents, humans utilize similar spaces in diverse ways.

Looking at the case of the Roman villa-which has been extensively documented and debated - is instructive in this regard, especially since the label has also been applied to Qumran. In fact, the term "villa" is highly problematic owing to there being too many types of buildings that have been described in this manner - not only by modern scholars but also by ancient writers, sometimes for ideological reasons. ${ }^{30}$ As a result, the term has lost its heuristic value, to the extent that it "is in need of a comprehensive redefinition." ${ }^{31}$ In the end, a villa was essentially a farmstead, ${ }^{32}$ and any hard distinctions between the two descriptors can be subjective and artificial. If one opts to delimit the term "villa" and describe it as a luxurious country residence attached to an agricultural estate, as many in fact do, what would the cut-off point be between this definition of a villa and a farmstead? Even then, the label would still fail to distinguish between low- and high-end villas, not to mention that it blurs the

Archaeology of Qumran, 21), weakens the claim that the Hasmonaeans must have controlled this tract of land.

For a range of villa types, see John T. Smith, Roman Villas: A Study in Social Structure (London: Routledge, 1997). For various methodological issues linked with the term "villa," see Annalisa Marzano, Roman Villas in Central Italy: A Social and Economic History, CSCT 30 (Leiden: Brill, 2007), 1-12; Mantha Zarmakoupi, "Private Villas: Italy and the Provinces," in A Companion to Roman Architecture, ed. Roger B. Ulrich and Caroline K. Quenemoen (Malden, mA: Blackwell, 2014), 363-80 (364-70).

31 Marzano, Roman Villas, 2.

32 Shimon Applebaum, "The Roman Villa in Judaea: A Problem," in Judaea in Hellenistic and Roman Times: Historical and Archaeological Essays, sJLA 40 (Leiden: Brill, 1989), 124-31 (124); Ze'ev Safrai, The Economy of Roman Palestine (London: Routledge, 1994), 47-48. 
socio-cultural and economic differences that could have characterized one socalled villa from another. ${ }^{33}$

In the case of Qumran, its identification as a type of farmstead, while not incorrect, fails to tell the whole story and it ignores the presence of unique features that are unattested at other sites of an agricultural or industrial character, such as the adjacent cemetery, the numerous large miqwa'ot, and the animal bone deposits. At the same time, even if the site was probably run by a group related to the Scrolls, the label "sectarian settlement" is unsatisfactory as it speaks of the general nature of the site more than its functions. It is clear that labels hinder, rather than help, comprehension, especially considering the multifaceted nature of settlements. What I am proposing, therefore, is somewhat paradoxical: Qumran has to be analysed and understood in its wider Mediterranean context, but ultimately this cannot replace a detailed site-specific analysis involving all its aspects.

I close this first note with a brief, but related, remark on the Scrolls as physical artefacts and the concept of libraries, and here I emphasize that this short discussion does not do justice to the complexity of the question at hand. Earlier discussions have often focused on whether or not Qumran was a library. In line with the above observations, this is quite reductionist and it overlooks the fact that buildings were multifunctional. Even if one assumes that most (if not all) of the Scrolls found in the caves at Qumran were once housed in the settlement-and for our purposes it does not matter whether this was somewhere within the buildings or in one or more of the adjacent artificial caves, particularly Cave $4 \mathrm{Q}$ - this does not suddenly turn Qumran into a "library," which is another highly misleading term. Once again, parallels from the Graeco-Roman world are helpful and they show that private buildings could have housed a "library" without such buildings being essentially libraries. The best archaeological parallel is perhaps the Villa of the Papyri in Herculaneum, where a small room (ca. $3.20 \times 3.20 \mathrm{~m}$ ) sufficed to hold hundreds of papyrus rolls. ${ }^{34}$ But a good number of other private villas and imperial residences with

33 See further Marzano, Roman Villas; eadem, "The Variety of Villa Production: From Agriculture to Aquaculture," in Erdkamp, Verboven, and Zuiderhoek, Ownership and Exploitation of Land, 187-206.

34 Daniele Delattre, La Villa des Papyrus et les rouleaux d'Herculanum: La Bibliothèque de Philodème, Cahiers de CEDOPAL 4 (Liège: CEDOPAL, Université de Liège, 2006), 16, 20-22, Pl. 3; George W. Houston, Inside Roman Libraries: Book Collections and their Management in Antiquity (Chapel Hill: The University of North Carolina Press, 2014), 88, 98-101, 186-87. 
rooms for book collections are also known, ${ }^{35}$ and literary sources similarly attest to the holdings of large collections of books in villas. ${ }^{36}$ The main difference, of course, is that these villas had an urban character, but that is beside the point. These examples still serve as a good analogy for Qumran, especially in light of Mladen Popović's recent depiction of the site as a locus where rural and urban culture meet. ${ }^{37}$ This is not surprising since rustic villas were likewise crossroads for the intersection of urban and rural culture-they were both agricultural units and luxurious retreats, with facilities for relaxation and entertainment. The interesting thing about Qumran, therefore, is not that rural and urban cultures converged there, but that leisurely pursuits were sought in study and learning rather than fine dining or entertainment.

Before proceeding further, it is necessary to acknowledge the inherent dangers of Mediterraneanism in any contextual approach of the type advocated here, ${ }^{38}$ although the benefits of a pan-Mediterranean perspective far outweigh the pitfalls. Irrespective of whether or not Qumran is considered as a site "bordering" the Mediterranean, ${ }^{39}$ the latter provides us with a reserve of data highlighting survival strategies in marginal zones, and these therefore allow us to posit hypotheses regarding daily life at Qumran. In the process, we are reminded that Qumran was part of a bigger, integrated ecological world. Furthermore, Qumran was also interconnected to a larger political and cultural world. As part of the "international" state set up by the Hasmonaeans and then Herod, and later as part of the Roman province of Judaea, Qumran was not only connected to regional settlements but it was also very much integrated within a "global" Mediterranean network - which brings us to the next point.

35 Lorne Bruce, "Palace and Villa Libraries from Augustus to Hadrian," JLH 21 (1986): 510-52.

36 Lionel Casson, Libraries in the Ancient World (New Haven: Yale University Press, 2001), 69-79; Ewen Bowie, "Libraries for the Caesars," in Ancient Libraries, ed. Jason König, Katerina Oikonomopoulou, and Greg Woolf (Cambridge: Cambridge University Press, 2013), 237-6o.

37 Mladen Popović, "The Ancient 'Library' of Qumran between Urban and Rural Culture," in The Dead Sea Scrolls at Qumran and the Concept of a Library, ed. Sidnie White Crawford and Cecilia Wassen, sTDJ 116 (Leiden: Brill, 2015), 155-67.

38 See also Seth Schwartz, Were the Jews a Mediterranean Society? Reciprocity and Solidarity in Ancient Judaism (Princeton: Princeton University Press, 2010), 21-44.

39 On defining the "Mediterranean," see footnote 3. Although I do think that Qumran can be classified as a "Mediterranean" site, this is beside the point. The cogency of the above observations relies on the definition of Qumran's microecology as a marginal zone, for which the Mediterranean provides us with pertinent analogies. 
The second note is about methodology. Situating Qumran in a GraecoRoman Mediterranean context inevitably raises the issue of "Hellenization" or "Romanization." Did the Qumranites embrace or did they shun, or else try to limit, Graeco-Roman influences and incursions? The question is fraught with problems. To begin with, the terms "Hellenization" and "Romanization" are notoriously problematic owing to the false impression they give in the evaluation of cultural interaction in antiquity. Misleadingly, these concepts imply that cultural influence or transmission was unidirectional and that it was imposed forcefully on a submissive population; essentially, the concepts rob people at the receiving end of their agency, turning them into passive consumers of nonindigenous cultural products and practices. ${ }^{40}$ Recent scholarship has turned the tide, laying emphasis on the idea of reciprocal cultural exchange; the importance of human agency and creative interaction with cultural artefacts and concepts; questions of identity and ethnicity; as well as notions of hybridity or hybridization, creolization, and glocalization, among others.

Accordingly, rather than focusing on evidence for or against "Hellenization" or "Romanization" at Qumran — how can we even measure this? - a better alternative may be to explore the nuances that emerge out of the cultural encounters propagated by the interconnected world created by Hellenistic and Roman imperialism. From this perspective, the question should not be whether or not the Qumranites were Hellenized or Romanized, but to describe and analyse the nature of interaction with non-indigenous traditions. This allows us to move away from the creation of dichotomies and to embrace more complex scenarios, which are a more realistic reflection of daily life in the ancient Mediterranean.

A good example of this approach is Matthew Richey's examination of the use of Greek at Qumran. Through an analysis of textual artefacts from Qumran (i.e., ostraca, inscribed stone artefacts, and the Scrolls), Richey does a fine job at

40 The literature is too vast. See, for example, Rachel Mairs, "Hellenization," in The Encyclopedia of Ancient History, ed. Roger S. Bagnall et al. (Malden, MA: Wiley-Blackwell, 2012), 3122-25; Ursula Rothe, "Romanization," in Bagnall et al., The Encyclopedia of Ancient History, 5875-81. And see further Greg Woolf, Becoming Roman: The Origins of Provincial Civilization in Gaul (Cambridge: Cambridge University Press, 2005); David J. Mattingly, Imperialism, Power, and Identity: Experiencing the Roman Empire (Princeton: Princeton University Press, 2011), 3-42; Mark A. Chancey, Greco-Roman Culture and the Galilee of Jesus (Cambridge: Cambridge University Press, 2005), 1-23; Lee I. Levine, Judaism and Hellenism in Antiquity: Conflict or Confluence? (Peabody, MA: Hendrickson, 1998). 
portraying a more nuanced picture, demonstrating that while the Qumranites preferred Hebrew and Aramaic texts, they did use Greek in daily life-for example, for economic purposes. ${ }^{41}$ Thus, the use of Greek seems to have been compartmentalized at Qumran. It is therefore not a question of whether or not Greek was used, but in what spheres of life it was employed.

My own example here focuses on the interpretation of imported artefacts. Questions of "Hellenization" or "Romanization" tend to give too much importance to the presence of certain artefacts which may be deemed to be evidence of "acculturation" or "assimilation," and these generally include certain imported fine or semi-fine wares. In particular, some scholars give much significance to the fact that some fragments of eastern terra sigillata may have been found at Qumran. ${ }^{42}$ There are also a few "Sidonian" glass vessels bearing Greek inscriptions, which are generally a variation on the theme of self-gratification and enjoyment or else complimentary to the drinker. ${ }^{43}$ The presence of these dining wares is customarily construed as a desire to emulate the lifestyle of the Graeco-Roman elite. Some scholars have even implied that the presence of these vessel types proves that Qumran was indeed a villa. ${ }^{44}$

Contextual problems aside, ${ }^{45}$ let us assume that these imported wares belonged to Period I/II. Would this necessarily imply that the Qumranites adopted Graeco-Roman dining practices and attitudes, or that they sought to appropriate or construct Graeco-Roman identities? To presume so deprives the Qumranites of their agency, while betraying a simplistic equation between

41 Matthew Richey, "The Use of Greek at Qumran: Manuscript and Epigraphic Evidence for a Marginalized Language," DSD 19 (2012): 177-97.

42 Magen and Peleg, "Back to Qumran," 68.

43 For a detailed overview of the glass vessels from Qumran, see Dennis Mizzi, "The Glass from Khirbet Qumran: What Does It Tell Us About the Qumran Community?" in The Dead Sea Scrolls: Texts and Context, ed. Charlotte Hempel, STDJ 9o (Leiden: Brill, 2010), 99-198. In the latter, I had entertained the notion that the "Sidonian" wares-should they prove to have belonged to Period I/II, which is uncertain — could betray Hellenistic attitudes among the Qumranites. Here, I deconstruct and abandon this claim.

44 See, for example, Robert Donceel and Pauline Donceel-Voûte, "The Archaeology of Khirbet Qumran," in Methods of Investigation of the Dead Sea Scrolls and the Khirbet Qumran Site: Present Realities and Future Prospects, ed. Michael O. Wise et al., ANYAS 722 (New York: The New York Academy of Sciences, 1994), 1-38; Hirschfeld, Qumran in Context, 142-52. Sometimes, the same notion comes through implicitly in critiques of these hypotheses. See, for instance, Jodi Magness, “A Villa at Khirbet Qumrân?” RevQ 16 (1994): 397-419; eadem, Archaeology of Qumran, 90-100.

45 At this point, it must be underlined that the date of many of these imported fine wares is uncertain since they come from unclear or mixed contexts (e.g., dumps). Some of the fine glassware comes from clear Period III levels. 
artefacts in the ground and a specific set of human practices. For how can we ascertain that the values the Qumranites applied to such wares conformed to those imbued on them in other parts of the Graeco-Roman world? Speaking for the situation in pre-conquest Gaul, Greg Woolf stresses the need to "draw a distinction between the consumption of Roman goods and Roman styles of

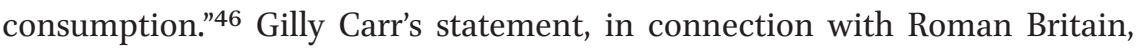
sums this up perfectly:

[T] he presence of Roman/imported Mediterranean material culture on a settlement does not prove that the inhabitants were Romanised. They may have been using Roman objects in a 'native' way for 'native' (i.e., indigenous, traditional) practices. ${ }^{47}$

Critically, these remarks are not merely theoretical. Quite the contrary, Woolf notes:

[B]oth classical accounts and a contextual approach to Mediterranean artefacts found at iron age sites suggest strongly that iron age populations used these imports in ways that were quite distinctive, and that the values they gave these exotics were rather different to those accorded them in the Roman world. ${ }^{48}$

Woolf goes on to highlight how pre-conquest Gauls' consumption patterns of Italian imports and associated dining practices differed from Roman ones, ${ }^{49}$ concluding that "Mediterranean imports were not acquired as devices to turn Gauls into Romans." ${ }^{50}$ Woolf offers an equally nuanced analysis regarding the use of terra sigillata following the Roman conquest of Gaul. ${ }^{51}$

\footnotetext{
46 Woolf, Becoming Roman, 176.

47 Gilly Carr, “'Romanisation' and the Body," in TRAC 200o: Proceedings of the Tenth Annual Theoretical Roman Archaeology Conference held at the Institute of Archaeology, University College London, 6th-7th April 20oo, ed. Gwyn Davies, Andrew Gardner, and Kris Lockyear (Oxford: Oxbow Books, 2001), 112-24 (117).

48 Woolf, Becoming Roman, 176.

49 Cf. his assessment of classical sources on the Gauls' consumption of Mediterranean wine: "Significantly, Greek and Roman observers did not see these feasts and wine drinking as a sign that Gauls shared classical values and customs: instead they presented the bizarre and excessive uses that the Gauls made of wine as confirmation of their barbarism" (Woolf, Becoming Roman, 177-78 [quote at 178]).

$50 \quad$ Woolf, Becoming Roman, 180.

51 Woolf, Becoming Roman, 181-205.
} 
Therefore, Mediterranean case studies provide us with concrete eye openers that should discourage us from simplifying or imposing fixed meanings on the interpretation of artefacts at Qumran (or any other site, for that matter). This means that the analysis of artefacts has to be contextualized within the overall material culture from the site under study. Objects need to be understood in relation to other objects; artefacts need to be analysed holistically as part of a bigger assemblage comprising pottery, glass and stone vessels, stone and metal implements, small finds, and coins, and also in relation to architecture.

In the case of Qumran, it is noteworthy that the few fragments of eastern terra sigillata are eclipsed by the exceedingly large amounts of common pottery. The majority of glass vessels likewise reflect the typical wares in circulation, with "Sidonian" wares comprising a clear minority. Certainly, one explanation could be that such imported wares were used only on special occasions, hence the higher consumption rates of common local wares. Even if this were the case, the use of fine wares for special meals does not turn these into GraecoRoman symposia, with all their associated trappings. Fine wares could have been used for Jewish festive meals (e.g., sabbath or festival meals). Indeed, the site lacks a lavish dining hall in which the Qumranites could have entertained and impressed their guests, unlike the luxurious houses in Jerusalem ${ }^{52}$ or the royal palaces in Jericho and Masada, ${ }^{53}$ for example. Even then, the fact remains that the ratio of common to imported wares (including ones not mentioned here) is exceedingly uneven.

What is noteworthy, however, is that this is not a simple question of whether or not the Qumranites could have afforded such vessels. In fact, there is plenty of evidence to show that the Qumranites were rather affluent, including three coin hoards containing over five hundred silver shekels and half-shekels, found in L120; ${ }^{54}$ a substantial corpus of chalkstone vessels which includes a particularly large number of jars (considerably more than is typical in village or rural contexts), which many scholars reckon to have been quite expensive; 55

52 Nahman Avigad, Discovering Jerusalem: Recent Archaeological Excavations in the Upper City (Oxford: Blackwell, 1984).

53 Ehud Netzer, The Palaces of the Hasmoneans and Herod the Great (Jerusalem: Yad Ben-Zvi Press; Israel Exploration Society, 2001).

54 De Vaux, Archaeology and the Dead Sea Scrolls, 34-35.

55 Mizzi, The Archaeology of Khirbet Qumran, 193-216. Further chalkstone vessels, including jars, have been found in the recent excavations, for which see Yitzhak Magen and Yuval Peleg, The Qumran Excavations, 1993-2004: Preliminary Report, JSP 6 (Jerusalem: Staff Officer of Archaeology_Civil Administration of Judea and Samaria; Israel Antiquities Authority, 2007), 21. 
and a large number of scrolls-assuming that the Scrolls belonged to the Qumranites-which were costly artefacts in the ancient world. The possibility that the Qumranites owned land, not to mention their involvement in lucrative industries, is further indication that they must have been relatively wealthy. Therefore, it seems that the Qumranites could have afforded expensive, imported wares, but instead they opted to invest in purity (if stone vessels fulfilled a function connected with purity) and in the knowledge economy. ${ }^{56}$ This is highly significant as it shows that the Qumranites could and did choose the type of material culture to consume or invest in. Critically, our analysis gives them back their autonomy and their capacity to be selective. Seen in this light, the presence of a few fragments of eastern terra sigillata and "Sidonian" glass vessels - if they did indeed belong to Period I/II, which is a big if-loses much of its significance, which highlights the fact that we cannot make simple equations between artefacts and alleged "Hellenization" or "Romanization."57

Of course, we can only speculate on the whys and wherefores of the presence of these imported wares at Qumran, and we could do worse than look at other case studies around the Mediterranean for analogies and patterns of use. Within the paradigm of the sectarian hypothesis, for example, one conceivable explanation for the small number of fine wares could be that these were possessions brought over by wealthy individuals who came to reside at Qumran. Other explanations are of course possible. The point is that we need to go beyond simple explanations which merely equate certain imported fine or semi-fine wares with a desire to be "Greek" or "Roman."

$5^{6}$ On the concept of "knowledge economy" applied to Qumran, see Charlotte Hempel, "It's the Economy, Stupid-Reflections on the Qumran Knowledge Economy," Opening Address, International Organization for Qumran Studies Meeting, 25 July 2017, Leuven, Belgium.

57 The picture is problematized further by the presence of imitations of eastern terra sigillata found in Period I/I contexts. On the one hand, this shows that the Qumranites were exposed to outside trends and influences; on the other, it indicates that they opted to purchase or produce imitations of foreign wares. Does this betray a desire to imitate GraecoRoman customs? But then, why not purchase the originals, especially if the Qumranites could afford them? The fact that the number of such imitations is negligible relative to the ceramic corpus as a whole cautions us, once again, not to overstate their importance. A brief discussion of these imitations can be found in Magness, Archaeology of Qumran, 76-77; Mizzi, The Archaeology of Khirbet Qumran, 132-33. 


\section{Qumran in the Light of other "Hellenistic" Sites: A Case Study on the Interpretation of $\mathrm{L}_{4}$}

My final note is a short case study. It is an example of how archaeological evidence from classical sites around the Mediterranean and beyond can be used to support new readings or interpretations of specific aspects of Qumran. It is critical that Qumran is not artificially transformed into a unique, one-ofa-kind site, irrespective of its interpretation. Sectarian or not, Qumran was a "Hellenistic" site situated in Judaea. Its inhabitants are, therefore, likely to have borrowed and used — consciously or subconsciously — architectural and technical metaphors circulating in the larger Hellenistic world.

The focus of this last note is on $\mathrm{L} 4$, which is a rectangular room with a plaster floor, plastered walls, and a $10-20-\mathrm{cm}$ high plaster bench built against all four of the room's walls (Figures $1-3) .{ }^{58}$ This room is located in the southwest corner of the so-called main building, and it appears to have been constructed sometime in the first century всЕ. ${ }^{59}$ On account of the benches, de Vaux interpreted L4 as an assembly room, ${ }^{60}$ whereas Hartmut Stegemann and now also

$5^{8}$ See de Vaux's description in Jean-Baptiste Humbert and Alain Chambon, ed., Fouilles de Khirbet Qumrân et de Aïn Feshkha: I: album de photographies, repertoire du fonds photographique, synthèse des notes de chantier du Père Roland de Vaux OP, NTOA.SA 1 (Fribourg: Academic Press Fribourg; Göttingen: Vandenhoeck \& Ruprecht, 1994), 293, Fig. XI, Pls. 86, 96, 101, 131-38. And see also Roland de Vaux, "Fouille de Khirbet Qumrân: rapport préliminaire," $R B$ 6o (1953): 83-106 (91-92, Fig. 1).

59 There are big debates about the architectural development of the settlement, and the present evidence is not adequate enough to determine precisely how it developed or when certain rooms were constructed. Nonetheless, it is widely agreed that the site reached its fully fledged form by the late first century всE. See Mizzi, "Qumran Period I Reconsidered," for a detailed discussion.

Once built, L4 was always equipped with the plaster bench, even though there is evidence of some changes, probably the result of maintenance and repairs. For instance, de Vaux identified two plaster floors, the lower one of which was contemporaneous with the southern part of the platform but anterior to the western and northern parts, both of which were coeval with the upper floor (see Humbert and Chambon, Fouilles de Khirbet Qumrân et de Aïn Feshkha, 293). The field notes are clear that, when de Vaux states that the platform "semble postérieure à un premier état de la pièce," or that he found another indication "que la banquette est d'un second état: deux sols de plâtre devant la porte, le plus haut en liaison avec la banquette," de Vaux was not speaking of the entire platform. In view of the door leading into L1, there is also the question of whether or not the southwest corner of the platform was original, but space does not permit me to discuss this issue here.

6o De Vaux, Archaeology and the Dead Sea Scrolls, 10-11, 32. 


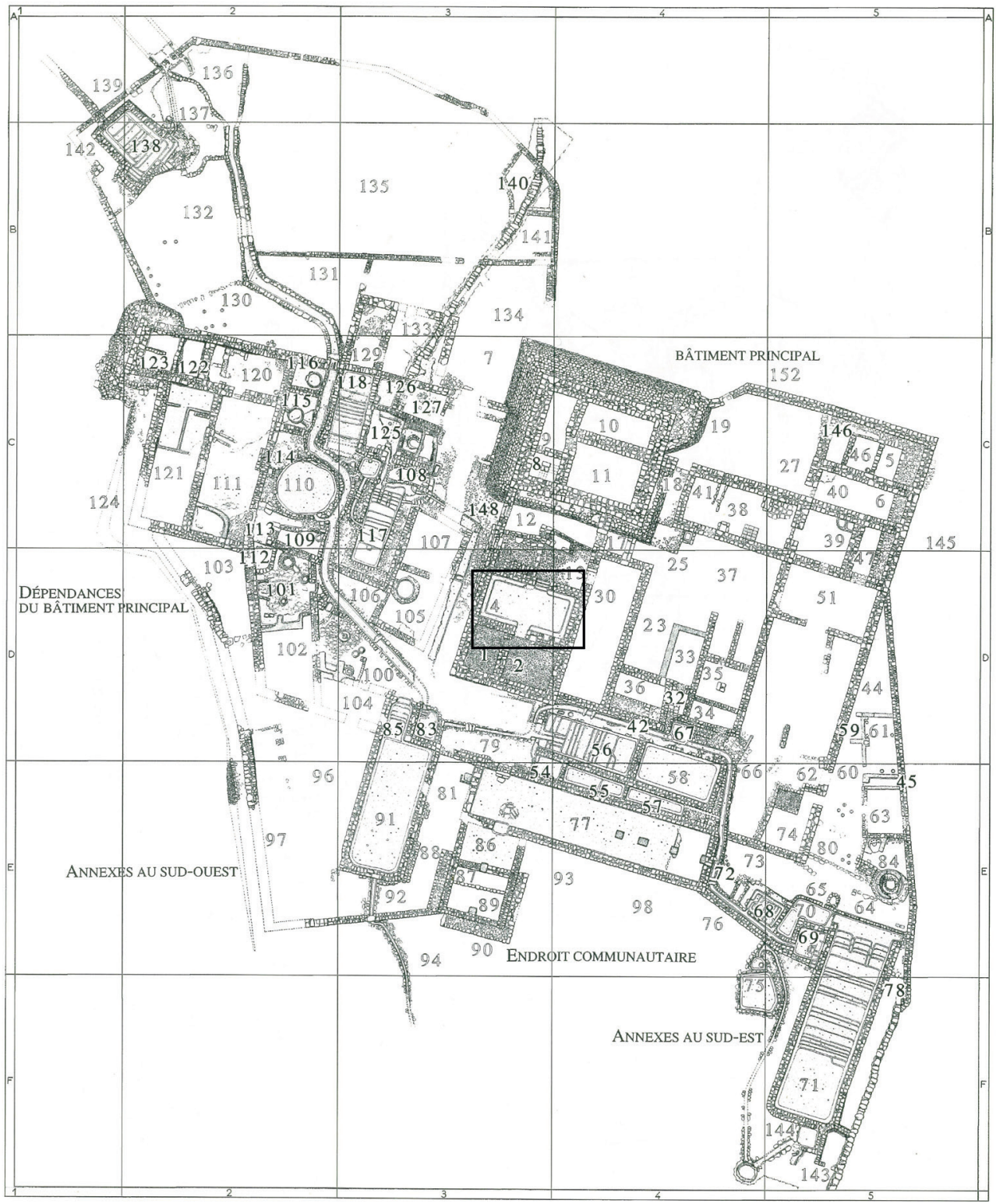

FIGURE 1 The settlement at Qumran during the first century $B C E-C E$, with a frame highlighting the location of $\mathrm{L}_{4}$.

COURTESY OF THE ÉCOLE BIBLIQUE ET ARCHÉOLOGIQUE FRANÇAISE DE JÉRUSALEM; MODIFICATIONS BY THE PRESENT AUTHOR 


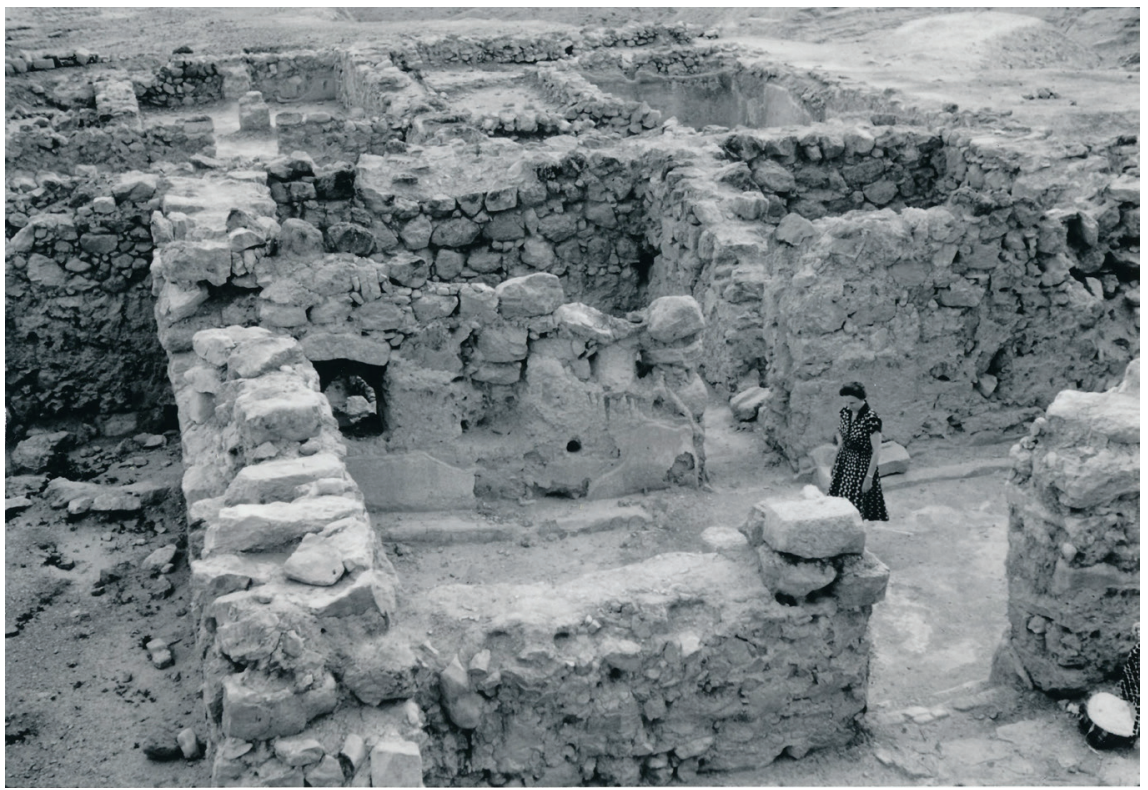

FIGURE 2 Qumran: L4, looking south to southwest. Note the low plaster bench along the south wall, the plaster along the wall, and the cupboard in the southeast corner of the room.

REPRODUCED WITH PERMISSION OF THE ALLEGRO ESTATE; COURTESY OF THE MANCHESTER MUSEUM, UNIVERSITY OF MANCHESTER

Ian Werrett suggest that it was a reading room, with the adjoining L1-2 having been used for the storage of scrolls. ${ }^{61}$ Yizhar Hirschfeld, on the other hand, objects that the plaster bench is too low for sitting and opines that $\mathrm{L}_{4}$, together with L1-2, might have functioned as a storage room, with the plaster benches serving to accommodate storage jars. ${ }^{62}$

Almost identical setups to L4 are known from Dura Europos, where they have been found in various houses from the late second and early third centuries CE (Figure 5). Many of the houses included at least one rectangular room equipped with a plaster bench running along the wall. The benches or raised platforms

61 Hartmut Stegemann, The Library of Qumran: On the Essenes, Qumran, John the Baptist, and Jesus (Grand Rapids, MI: Eerdmans, 1998), 39-40; Ian C. Werrett, “Is Qumran a Library?" in Crawford and Wassen, Concept of a Library, 78-105 (94-96).

62 Hirschfeld, Qumran in Context, 96, 100, esp. Fig. 49; followed by Robert R. Cargill, Qumran through (Real) Time: A Virtual Reconstruction of Qumran and the Dead Sea Scrolls, BiT 1 (Piscataway, NJ: Gorgias Press, 2009), 111-12. 


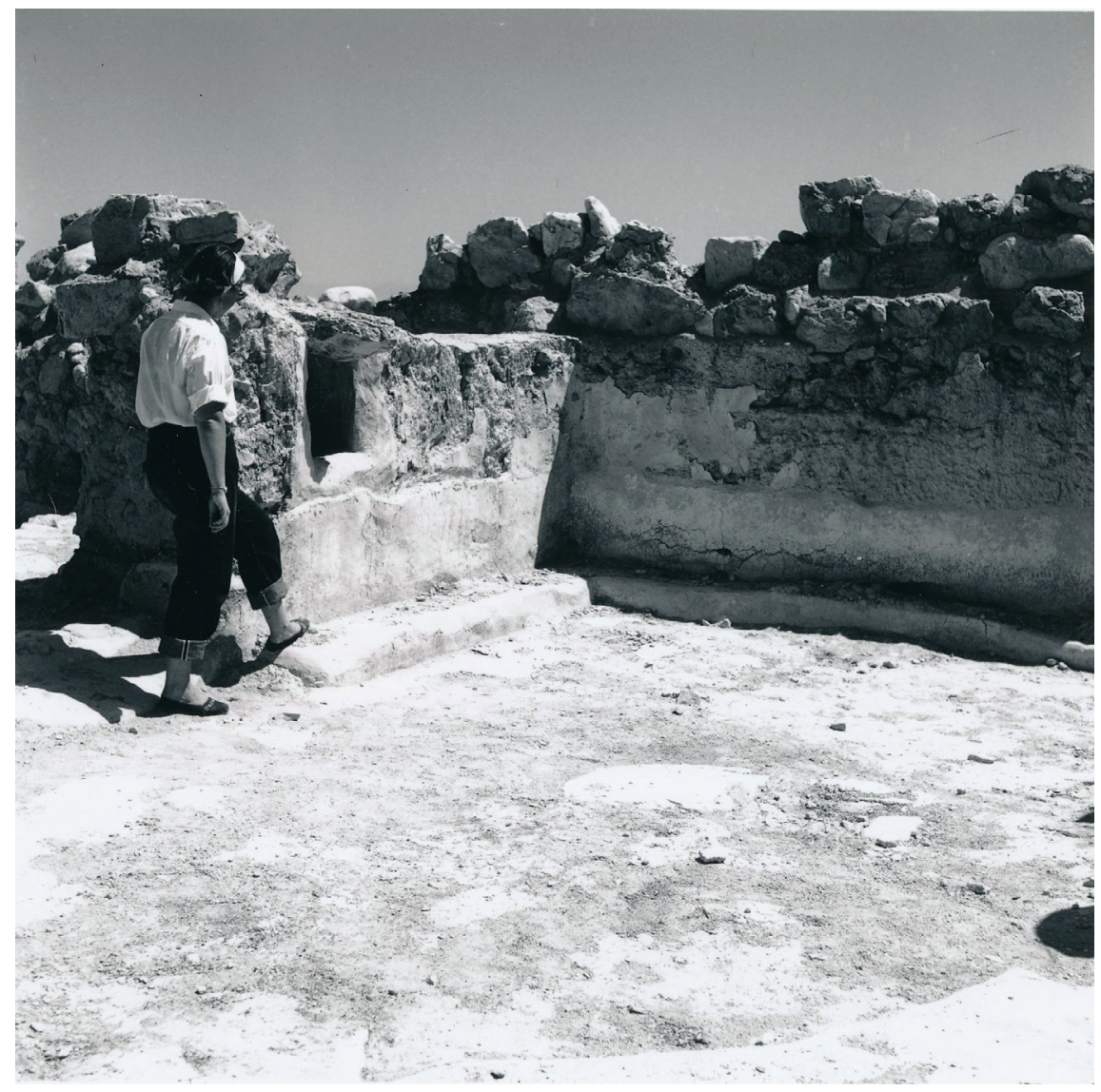

FIGURE 3 Qumran: L4, looking northeast. Note the low plaster bench along the east and north walls, the plaster along the walls, and the "basin" to the east of the north door. REPRODUCED WITH PERMISSION OF THE ALLEGRO ESTATE; COURTESY OF THE MANCHESTER MUSEUM, UNIVERSITY OF MANCHESTER

are only $10-20 \mathrm{~cm}$ high, and they are interpreted as bases for reclining couches, akin to the klinai-bands one finds in Greek and Hellenistic dining rooms (which are typically higher). That the rooms' primary purpose was for dining and/or reception is suggested by their spatial context, the decorated walls, and the finely built entrances. ${ }^{63}$ Rooms equipped with a low dais are also attested in various sixth-fifth century BCE buildings associated with the sanctuary

63 Jennifer A. Baird, The Inner Lives of Ancient Houses: An Archaeology of Dura Europos (Oxford: Oxford University Press, 2014), 70-83, and see esp. Fig. 2.7. 


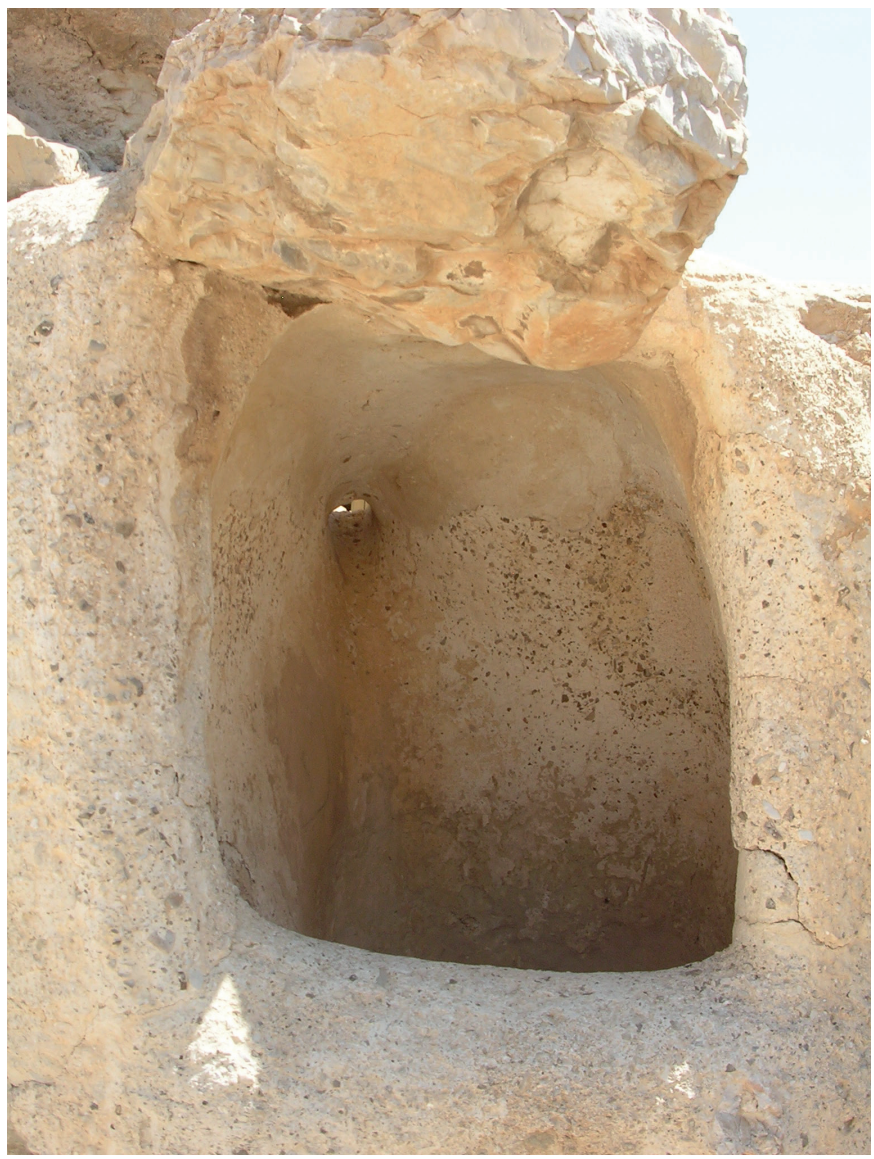

FIGURE 4 "Basin" to the immediate east of the north door of L4.

(C) DENNIS MIZZI

of Demeter in Corinth; these are likewise interpreted as dining rooms and the platforms are understood as bases for reclining couches. ${ }^{64}$

Despite some differences (e.g., construction technique, design, dimensions, number of doorways in the room, etc.), the plaster bench in $\mathrm{L} 4$ could be interpreted in an analogous manner. Seeing that its depth is ca. $30-40 \mathrm{~cm}$, it is unlikely that it accommodated reclining couches, which typically were ca. 80-90

64 Nancy Bookidis and Ronald S. Stroud, Corinth: Results of Excavations Conducted by The American School of Classical Studies at Athens: Volume XVIII, Part III: The Sanctuary of Demeter and Kore: Topography and Architecture (Princeton, NJ: The American School of Classical Studies at Athens, 1997), 393-402, esp. 400. 


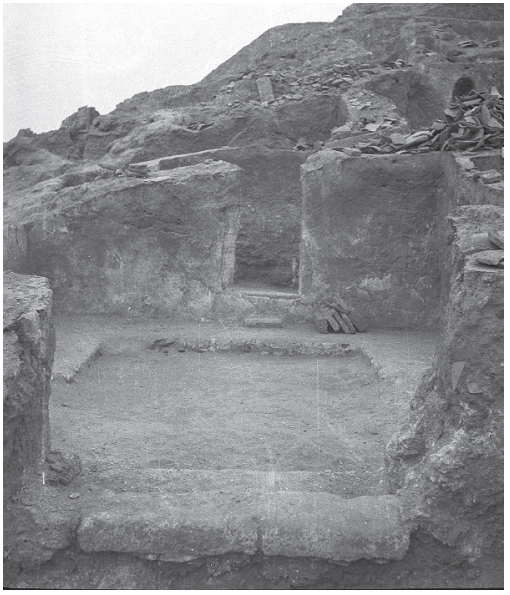

FIGURE 5

Private house at Dura Europos: low plaster bench around room $C_{3}-D 9$.

COURTESY OF YALE UNIVERSITY ART GALLERY, DURA EUROPOS COLLECTION: YUAG FXI 48

cm wide (triclinia were even wider, with documented widths of ca. $1.50 \mathrm{~m}$ ). ${ }^{65}$ On the other hand, the width (but not the height, which is significantly lower) fits those of seats in the ancient world, including seats found in early and late Roman as well as Byzantine contexts in ancient Palestine, where depths ranging from a little less than $30 \mathrm{~cm}$ to more than $80 \mathrm{~cm}$ are documented. ${ }^{66}$ Therefore, people sat and did not recline in $\mathrm{L} 4 .{ }^{67}$ In this case, the low plaster bench is likely to have served as a base accommodating wooden seats-that is, the bench was not the actual surface on which people sat, hence making any objections concerning its low height moot. ${ }^{68}$ The function of such a plaster bench would have been to protect the base or bottom of wooden seats from

65 Bookidis and Stroud, The Sanctuary of Demeter, 393-402; Katherine M. D. Dunbabin, "Ut Graeco More Biberetur: Greeks and Romans on the Dining Couch," in Meals in a Social Context: Aspects of the Communal Meal in the Hellenistic and Roman World, ed. Inge Nielsen and Hanne Sigismund Nielsen, ASMA 1 (Aarhus: Aarhus University Press, 1998), 88-101.

66 See the survey in Chad S. Spigel, Ancient Synagogue Seating Capacities: Methodology, Analysis and Limits, TSAJ 149 (Tübingen: Mohr Siebeck, 2012), 55-61.

67 Pace Susan Marks, "Reconsidering Reclining at Qumran," JAJ 7 (2016): 86-101. Marks makes a case for reclining at Qumran, but she fails to consider L4, and her argument is weakened by a lack of archaeological evidence for reclining elsewhere at the site.

68 Although it is tempting to see the bench as the actual surface on which people sat, this is unlikely. Certainly, such a feature would have been perfectly suited for sitting crosslegged, with the body on the low bench and the feet cross-legged on the floor. Cushions or pillows could have been placed on the bench for this purpose. Ultimately, however, the plaster bench would have been unnecessary for this sitting position. In contrast, it would 
moisture damage resulting from the washing of the floor ${ }^{69}$ Of course, rooms equipped with stone seating would have had no need for such bases.

Therefore, the interpretation of L4 as a room for sitting seems correct, but this interpretation can be unpacked even further. A room with sitting arrangements could have been used for a variety of purposes, including meetings, prayers, reading, and dining - $\mathrm{L} 4$ could have been the actual dining room of the Qumran settlement. ${ }^{70}$ It is surprising that no one has ever ventured this interpretation with regard to L4, although this is probably because $\mathrm{L}_{77}$ has been assigned this function, a reading that enjoys wide popularity among scholars. In view of the parallels from Dura Europos and Corinth, the function of $\mathrm{L}_{4}$ as a dining room is hard to dismiss. Lest we fall into the trap of parallelomania and assume that similarity of form indicates similarity of function, it is critical for this understanding of $\mathrm{L}_{4}$ to be supported by other pieces of evidence. The data, though not conclusive, do not disappoint in this case.

First, there is actual physical evidence for a sitting arrangement. Secondly, around one hundred pottery vessels were discovered in L4, many of which seem to have been found right above the Period II floor or on the bench., These consist of jars, plates, bowls, goblets, cooking pots, kraters, flasks, jugs, and juglets, with table vessels making up ca. $42 \%$ of the assemblage. ${ }^{71}$ This repertoire is

have had a very important function if the room was equipped with wooden seats (see main text).

69 See, for example, Elizabeth P. Baughan, Couched in Death: Klinai and Identity in Anatolia and Beyond (Wisconsin: University of Wisconsin Press, 2013), 28, 44 (and references there), here speaking about archaic and classical Greek dining rooms and klinai as background to her study of funerary couches in the ancient Mediterranean.

70 Contemporary literary sources indicate that Jews either sat or reclined during meals. While the former could have entailed sitting on the ground, some sources refer specifically to the use of seats. The Temple Scroll $\left({ }_{11 T^{a}} 37: 8-9\right)$, for instance, prescribes the construction of seats and tables for the consumption of sacred meals in the temple. See further Jodi Magness, Stone and Dung, Oil and Spit: Jewish Daily Life in the Time of Jesus (Grand Rapids, MI: Eerdmans, 2011), 81-82.

71 The corpus from $\mathrm{L}_{4}$ includes a large number of pottery which de Vaux had collected but not catalogued, and thus it is not listed in Humbert and Chambon, Fouilles de Khirbet Qumrân et de Aïn Feshkha, 293. I thank Jean-Baptiste Humbert for kindly sharing this information with me and for giving me permission to mention it here.

The majority of the vessels lack a date of registration, and thus their stratigraphic context cannot be established with certainty. It is possible that some of the vessels were found above the Period In floor. It is also possible that the vessels fell from the upper storey in L4 or that they were part of the levelling fill deposited there to accommodate the Period III floor. However, this is what de Vaux says regarding the pottery found in L4: "Sur le sol à l'angle ouest de la porte, plusieurs lampes à bec arqué. Au coin sud-est, restes 
more congruent with the utensils one expects to find in a dining room than the ceramic material from L 77 is. ${ }^{72}$ Thirdly, L4 included two cupboards or niches in its southeast corner (Figure 2) as well as a small "basin" (with a small channel at the top which opens into L13) raised above the floor and built into the north wall of L4, right to the east of the door (Figures 3-4).73 The cupboards were probably fitted with wooden shelves for the storage of tableware and other utensils. The "basin" in the north wall was possibly a "firebox" or brazier, ${ }^{74}$ and significantly this is another feature typical of the benched rooms at Dura Europos. ${ }^{75}$ Fourthly, L4 was practically adjacent to the cooking area in L38/41, thereby making the transfer of cooked food from cooking to dining area more straightforward than would have been the case with L77, although this piece of evidence must be used with caution. ${ }^{76}$

d'une cruchette. Beaucoup de poterie entre le haut de la banquette et le sol, poterie aussi sur la banquette" (Humbert and Chambon, Fouilles de Khirbet Qumrân et de Aïn Feshkha, 293). A large part of the pottery, therefore, seems to have been associated with the activities that took place in the lower storey of the room.

72 For the pottery from L77, see Humbert and Chambon, Fouilles de Khirbet Qumrân et de Aïn Feshkha, 317; Jean-Baptiste Humbert, Alain Chambon, and Jolanta Młynarczyk. Khirbet Qumrân et Aïn Feshkha: Fouilles du P. Roland de Vaux: IIIa: L'archéologie de Qumrân, NTOA. SA 5a (Göttingen: Vandenhoeck \& Ruprecht, 2016), 324-25, Pls. 52-53.

73 See the description in Humbert and Chambon, Fouilles de Khirbet Qumrân et de Ä̈n Feshkha, 291-92, 293, Fig. XI; Pls. 133-34, 143; de Vaux, Archaeology and the Dead Sea Scrolls, 10, Pls. VI, XVII.

74 De Vaux's interpretation of this feature as a water basin that was used during closed sessions of the assembly is convoluted and ultimately unconvincing (de Vaux, Archaeology and the Dead Sea Scrolls, 10-11). More plausibly, the "basin" could have been used to warm the room or, more likely, to keep food warm or boil liquids. The lower part of the feature, the basin proper, would have served as the container for the charcoal, whereas the open upper part would have accommodated pottery vessels, including cooking jugs. The small opening at the top would have channelled smoke or steam outside, in L13, which was a small courtyard.

75 Baird, The Inner Lives of Ancient Houses, 74. In the Dura Europos houses, the fireboxes are usually built into one end of the raised platform, not high up into the wall as in L4. Therefore, the parallel is not perfect when it comes to the specific details, but in more general terms it remains a valid parallel nonetheless - that is, the presence of a firebox or brazier, wherever its location, was a feature of some dining rooms in antiquity.

76 The notes for L38/41 are a bit confusing, and it is unclear how many floors de Vaux detected here. It is also uncertain whether or not $\mathrm{L}_{3} 8 / 41$ always functioned as a kitchen or whether this was a function associated only with its later phases. See de Vaux's notes in Humbert and Chambon, Fouilles de Khirbet Qumrân et de Ä̈n Feshkha, 305, 306. And see the preliminary report in Roland de Vaux, "Fouilles de Khirbet Qumrân: rapport préliminaire sur la deuxième campagne," $R B$ 61 (1954): 206-36 (210), where he considers L38/41 
All things considered, L4 seems to be a stronger candidate than $\mathrm{L} 77$ for the location of the settlement's dining room. In making this statement, it is necessary to emphasize that the archaeology of rooms is never straightforward. In particular, identifying dining rooms in the archaeological record of domestic settlements can be tricky, especially if the site in question did not have the trappings typical of elite houses of the Graeco-Roman period. ${ }^{77}$ Therefore, one should not expect too much of the evidence from Qumran. ${ }^{78} \mathrm{~L} 77$ happens to have pride of place as the settlement's dining room simply because of the history of scholarship, which has established this identification very early on. However, when one looks at $\mathrm{L} 77$, the evidence for its function as a dining room is not impressive, ${ }^{79}$ and it is certainly not a stronger contender than L4. Indeed,

to have functioned as a kitchen already during his Period Ib. Furthermore, if the dining room in L77 was moved to the upper storey in the first century $\mathrm{CE}$, as Magness suggests (Archaeology of Qumran, 6o, 122-26), it would have had easy access to L38/41 through the staircase in L35.

77 In these contexts, dining rooms can be recognized on the basis of a combination of features, the most important of which are the presence of reclining couches (if these were made of stone) or features or decoration on the floor marking out the space for the couches (if these were made of perishable or portable material). Other indicators include dining equipment, floor and/or wall decoration, as well as the spatial context. See, for example, Katherine M. D. Dunbabin, "Triclinium and Stibadium," in Dining in a Classical Context, ed. William J. Slater (Ann Arbor, MI: The University of Michigan Press, 1991), 121-48; Katherine M. D. Dunbabin and William J. Slater, "Roman Dining," in The Oxford Handbook of Social Relations in the Roman World, ed. Michael Peachin (Oxford: Oxford University Press, 2011), 438-66, esp. 441-49; Dennis E. Smith, From Symposium to Eucharist: The Banquet in the Early Christian World (Minneapolis, MN: Augsburg Fortress, 2003), 14-18, 25-27, Figs. 1, 3-4.

78 Qumran was no elite residence. Despite the discovery of a few decorative elements, it is unlikely that these were ever employed at Qumran. See the detailed discussion in Mizzi, "Qumran Period I Reconsidered," 30-40.

79 There are two main pieces of evidence that could identify $\mathrm{L}_{77}$ as a dining room - the pottery stockpile in the adjacent L86/87/89 and table vessels found above the plaster floors of L77 - and both could be equally and plausibly indicative of other activities. The pottery in L86/87/89 demonstrates that this annexe was used as a storage for pottery, but any further inferences-for example, that this space was a pantry—is purely an interpretation and it must be acknowledged as such. In other words, there is nothing obvious that identifies L86/87/89 as a pantry and (by extension) L77 as a dining room.

Other features that are often brought to bear on this interpretation of L77 are equally problematic. For example, the fact that the northern wall of L77 had a water inlet and that the floor of the locus sloped towards the southeast has been construed as a setup to clean the room following meals. See, for example, de Vaux, Archaeology and the Dead Sea Scrolls, 11; Magness, Archaeology of Qumran, 53, 122; Bart Wagemakers and Joan E. Taylor, 
if the evidence from L4 may seem inconclusive or even weak, that from L77 is even more so. In the end, not only does $\mathrm{L}_{4}$ have more corroborating evidence than L77 in this regard, but it also has the most important indicator-namely, a platform that most plausibly served as a base for wooden seats. ${ }^{80} \mathrm{~L}_{4}$ is the only room at Qumran with clear evidence for a sitting arrangement.

Identifying $\mathrm{L}_{4}$ as a dining room does not exclude other functions. In antiquity, as today, spaces were multifunctional. For instance, in the Dura Europos benched rooms, evidence for industrial and household production as well as religious activity was discovered. For this reason, Jennifer Bairns prefers to call this architectural unit a "principal room," but acknowledges that "formal dining was the most important use." 81 In similar fashion, L4 could have been used for meetings, prayer, study, reading, and dining. Indeed, some of these activities were intricately intertwined in the ancient world. For example, several classical and Jewish sources demonstrate that eating, drinking, and learned conversation (in lieu of music and entertainment) were two sides of the same coin. ${ }^{82}$ In this sense, therefore, $\mathrm{L}_{4}$ can be characterized as a multipurpose assembly room - in it, the Qumranites could have gathered for a wide variety of

"New Photographs of the Qumran Excavations from 1954 and Interpretations of L.77 and L.86," PEQ 143 (2011): 134-56 (135-42). But then, how does one explain the fact that the water inlet was blocked in de Vaux's Period Ii? Magness (Archaeology of Qumran, 6o, 122-26) suggests that, after L86/87/89 had suffered damage in 31 вСE (i.e., the end of de Vaux's Period $\mathrm{Ib}$ ), the dining room was first moved to the second storey of the western building, above L111, L120, L121, L122, and L123, and then moved again to the second storey above L77. While plausible, the evidence Magness adduces — another pottery stockpile in L114 (near the presumed dining room in the second storey of the western building), table vessels dumped in L56 (near the other presumed dining room in the upper storey in L77), and animal bone deposits close to both hypothetical dining rooms - is inconclusive. In and of themselves, none of these pieces of evidence prove definitely that there were two further dining rooms in the second storey of the western building and L77, respectively.

$80 \quad$ See footnote 77 .

81 Baird, The Inner Lives of Ancient Houses, 73-78 (quote at 73); eadem, "The Bizarre Bazaar: Early Excavations in the Roman East and Problems of Nomenclature," in TRAC 2006: Proceedings of the Sixteenth Annual Theoretical Roman Archaeology Conference, ed. Ben Croxford et al. (Oxford: Oxbow Books, 2007), 34-42.

82 See Smith, From Symposium to Eucharist, passim, and esp. 133-72, in which he discusses the Jewish banquet. Smith also underlines the connection between meals and study of the law in the Community Rule (1QS 6:3-8): "It is notable that the study of the law is here connected with the assembly for the meal, corresponding to similar references in Ben Sira and the Mishnah, and in Philo's description of the meals of the Therapeutae... This can be related to the philosophical tradition whereby elevated conversation was to be the symposium entertainment" (153-54). 
purposes, and important among these were the partaking of everyday meals and dining.

Certainly, this conclusion raises several other questions (e.g., what was, then, the function of $\mathrm{L} 77$ ?; could it still have been a dining room?; could there have been multiple dining rooms, some of which were used for specific occasions?; how does the architectural development of the site affect this interpretation of L4?), and it has implications for other conversations concerning the site (e.g., what was the population size at Qumran?). But this is beyond the scope of this brief note, and these questions will be explored thoroughly elsewhere. The point here was to illustrate the interpretative benefits we can reap once we broaden the horizons and seek analogies beyond the immediate geographical context of Judaea and the Dead Sea or the chronological parameters of the first centuries BCE and CE. ${ }^{83}$ The key is to keep in mind that any such parallels provide us with nothing more than analogies which we can then apply to an interpretation of site-specific data. In other words, the analogies cannot replace a detailed archaeological analysis of the site in question, and they cannot override local historical and cultural considerations. In the case of $\mathrm{L} 4$, we can borrow the archaeological data garnered from Hellenistic dining rooms without taking along the associated cultural baggage. ${ }^{84}$

Through these three brief reflections, I hope to have shown the benefits of adopting a pan-Mediterranean approach to the study of Qumran. The point is not to understand Qumran or the Qumranites through the deterministic lens of Mediterraneanism, but to use data from around the Mediterranean (loosely defined) as a source of interpretative analogies or a tool for gap-filling. In other words, the Mediterranean is nothing but a heuristic tool. Looking at this larger world, while acknowledging the propensity for local twists, helps us generate new insights on Qumran. The site may have been in the middle of the desert, but in the end it was both part of a larger ecological system and integrated with the "globalized" world of classical antiquity.

83 Cf. Jodi Magness's recent reappraisal of the animal bone deposits in "Were Sacrifices Offered at Qumran? The Animal Bone Deposits Reconsidered," JAJ 7 (2016): 5-34. Magness's reinterpretation of the evidence is very much informed by zooarchaeological data from cultic sites or sanctuaries in the ancient Near East and the Graeco-Roman world at large.

84 By the same argument, it is important to underline that the parallels do not have to be exact in comparative studies of this kind. General ideas could have been borrowed and given a local twist, depending on the necessities of a site's inhabitants. 